\title{
EXPERIMENTÁLNÍ TEST POŽÁRNÍ ODOLNOSTI DŘEVĚNÉ KONSTRUKCE
}

\author{
EXPERIMENTAL FIRE RESISTANCE TEST OF TIMBER STRUCTURE
}

\author{
Tomáš Žajdlík ${ }^{*}, 1$, Karel Šuhajda ${ }^{1}$
}

*zajdlik.t@ffee.vutbr.cz

${ }^{1}$ Vysoké učení technické v Brně, Fakulta stavební, Veveří 331/95, 60200 Brno

\begin{abstract}
Abstrakt
Použití dřevěných materiálů pro konstrukce v budovách má nesporné výhody. Stejně jako pro ostatní materiály platí pro jejich použití pravidla a omezení vyplývající především z jejich mechanicko-fyzikálních vlastností. $\mathrm{S}$ užitím dřevěné konstrukce v objektu dochází ke zvýšení požárního zatižení a zpřísnění požadavků na celkové řešení z hlediska požární bezpečnosti. Hořlavá nosná konstrukce má vliv na návrh objektu z hlediska jeho funkce, dispozičního řešení, užití samotných materiálů a požárně bezpečnostních zařízení. Údaje o chování dřevěných materiálů při působení požáru jsou zásadní pro správný návrh konstrukce s požadovanou požární odolností. Článek se zabývá experimentálním testováním materiálů a konstrukcí na bázi dřeva vystavených extrémním návrhovým situacím jako jsou účinky požáru.
\end{abstract}

\section{Klíčová slova}

Dřevostavba, degradace dřeva, zuhelnatělá vrstva, požární zkouška

\begin{abstract}
Wooden materials have many advantages for their use in buildings. There are many limitations for their use as with other materials. It's because of the mechanical-physical properties of natural wood. With the use of the wooden structure of the building, the fire load is increased and the requirements for the fire safety solution are stricter. The combustible load-bearing structure influences the design of the building in terms of its function, layout solution, structural materials, and fire safety equipment. The data of the behaviour of wooden materials in the event of fire are necessary for the correct design a timber structure with the required fire resistance. This paper is focused on experimental testing of timber structures exposed to extreme situations such as the effects of fire.
\end{abstract}

\section{Key words}

Timber structure, wood degradation, char layer, fire test

\section{1 ÚVOD}

Přirozené vlastnosti dřeva dělají z této základní suroviny vhodný materiál pro stavební prvky at už z environmentálního hlediska jako obnovitelný zdroj, tak z hlediska konstrukčního díky mechanicko-fyzikálním vlastnostem, potažmo vlastnostem určující jeho chování při požáru. Oproti oceli je tak dřevo poměrně stabilní materiál s předvídatelnou odezvou na účinky požáru.

Přri řešení otázky požární odolnosti dřevostaveb lze tyto objekty rozdělit na lehké dřevostavby (u kterých je požární odolnost zajištěna obvykle obkladovými materiály s třídou reakce na oheň především A1 a A2) a těžké dřevostavby (kde odolnost vưči účinkům požáru je dána samotnými rozměry dřevěných prvků a rychlostí jejich odhořívání) [1]. Návrh samotné dřevěné nosné konstrukce podléhá stejně jako u ostatních konstrukcí statickému posouzení, včetně posouzení mezního stavu nosnosti z hlediska požární odolnosti. Na základě chování dřeva při požáru je možné posouzení nosnosti řešit metodou účinného průřezu, metodou redukované pevnosti a tuhosti, či jejich kombinací pomocí metody obecné. Nejrychlejší a nejjednodušší je metoda založená na redukci rozměrů prvku, tj vyloučení plochy zuhelnatělé vrstvy v prưř̌zu prvku. Velikost zbytkového průřezu je pak závislá na rychlosti př́růstku této zuhelnatělé vrstvy dřeva, která je získána na základě zkoušek.

Zkoušení požární odolnosti je důležité pro získání podrobných výsledků jak o chování dřeva, tak celých konstrukčních prvků se zabudovanými dřevěnými prvky, na základě kterých je možné rozšśřit využitelnost dřevostaveb. 


\section{POPIS SOUČASNÉHO STAVU}

Požadavky na požárně bezpečnostní řešení jsou z pohledu zahraniční legislativy nejednotné. Jednotlivé státy mají různé nároky na objekty s konstrukčním systémem na bázi dřeva. $V$ rámci požárních předpisů ČR je dřevo vnímáno negativně jako hořlavý materiál, což se odráží v celkovém zatřídění konstrukčního systému stavby. Samotné konstrukční prvky na bázi dřeva jsou vyráběny s vysokými nároky na jejich vlastnosti. Řešení dřevostaveb z požárního hlediska přináší do celkového návrhu těchto druhů objektů značné limity a omezení, které se odráží na jejich celkovém počtu mezi novou výstavbou na našem území. Dřevostavby mají v ČR stále nízké procento zastoupení v porovnání $\mathrm{s}$ výstavbou objektů s nosnou konstrukcí z tradičních keramických staviv či materiálů na silikátové bázi. Dřevo se tak ve stavebních objektech u nás objevuje spíše ve formě jednotlivých konstrukčních prvků, tvořících jen zlomek z celkového materiálového podílu. Dřevostavby se zatr̂́íněním do skupiny OB1 (převážně rodinné domy) u nás zaujímají stále pouze přibližně $16 \%$ z celkové výstavby.

Hodnocení odolnosti konstrukcí vưči požáru je řešeno na základě normových požadavkủ, které vycházejí jak z mezinárodních světových norem, tak z legislativních požadavků platných pouze pro území ČR. Zásadními limity pro dřevostavby na našem území se pak stává např́klad kategorizace požární otevřenosti obvodových pláštů, kategorizace druhů konstrukčních částí DP1, DP2 a DP3 (oproti evropskému modelu kategorizace K1 a K2). Dle definice jednotlivých druhů pak konstrukce dřevostaveb lze zatř́ídit pouze do kategorií DP3, DP2. Tato skutečnost ovlivňuje následné další zatř́idění těchto objektů do kategorie staveb s hořlavým konstrukčním systémem. $\mathrm{Z}$ pohledu projektových norem toto zatřídění přináši řadu omezení $\mathrm{v}$ rámci posuzování jednotlivých oblastí požárně bezpečnostního řešení stavby. Jednotnou klasifikací pak zůstává kategorizace mezních stavů požární odolnosti a již zaužívané dělení materiálů dle jejich tř́́dy reakce na oheň.

\section{Chování dřeva při účincích požáru}

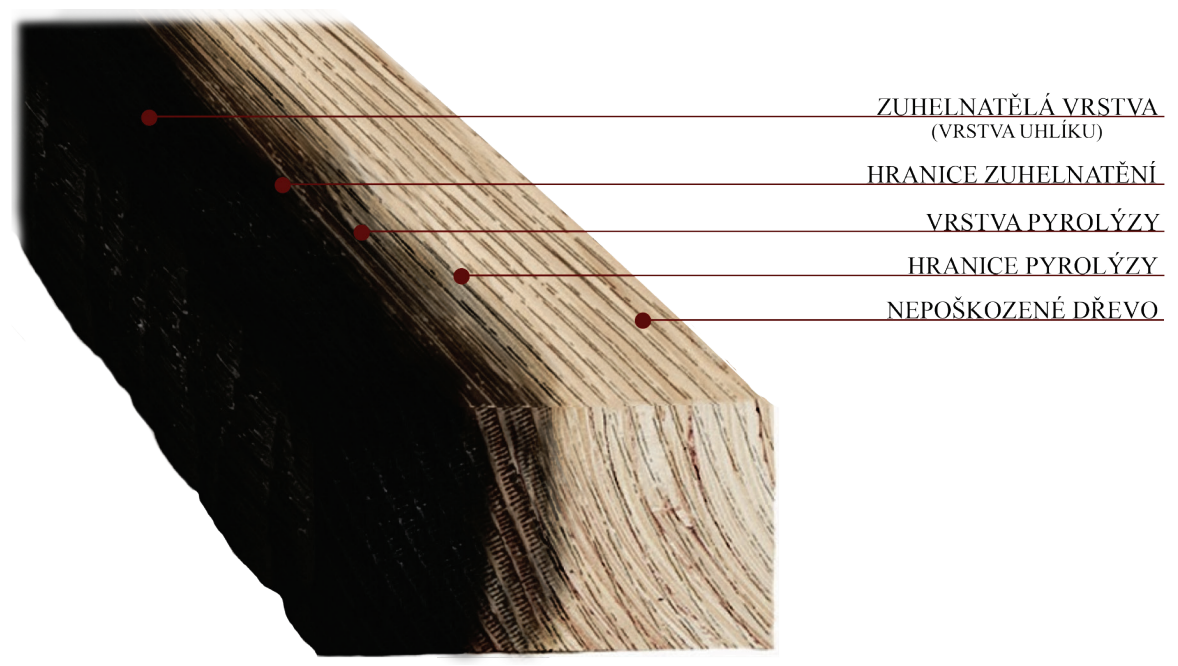

Obr. 1 Schéma degradace dřeva při hoření a tvorba zuhelnatělé vrstvy [2].

Př̌i působení zvýšené teploty na dřevěný prvek dochází k dehydrataci dřevní hmoty a odpařování vody. Při teplotách $100-150^{\circ} \mathrm{C}$ dochází $\mathrm{k}$ celkové ztrátě volné vlhkosti. S dalším zvyšováním teploty dochází $\mathrm{k}$ odpařování vody chemicky vázané. Teploty nad $150^{\circ} \mathrm{C}\left(150-250^{\circ} \mathrm{C}\right)$ způsobují rozklad hemicelulózy a následně mírný rozklad celulózy. Intenzivní termický rozklad a výraznější depolymerizace nastává při teplotách okolo $300^{\circ} \mathrm{C}$. Tato teplota je také považována za teplotu, při které dochází ke vzplanutí dřeva. Př̀i dalším nárůstu teploty dochází k výraznějšímu rozkladu ligninu. Největší množství hořlavých plynů vzniká při teplotách $400-420{ }^{\circ} \mathrm{C}$ [3]. Během hoření vzniká na povrchu dřeva vrstva nespáleného uhlíku s nižší objemovou hmotností, působící jako izolační vrstva (s nízkou tepelnou vodivostí), brání př́istupu kyslíku $\mathrm{k}$ dřevní hmotě a zpomaluje proces další termické degradace dřeva. Zuhelnatělá vrstva podléhá degradaci při dalším zvyšování teploty $\left(450-500{ }^{\circ} \mathrm{C}\right)$. Tloušt'ka zuhelnatělé vrstvy dřeva závisí na návrhové rychlosti zuhelnatění $\beta_{0}$ a $\beta_{n}[\mathrm{~mm} / \mathrm{min}$ ] [4]. Proces termické degradace dřeva je viditelný na Obr. 1 . 


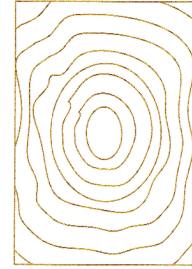

a)

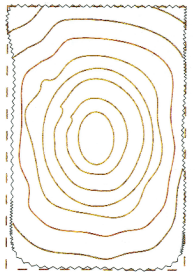

b)

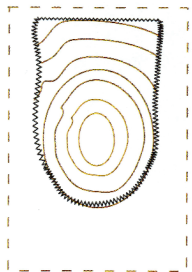

c)

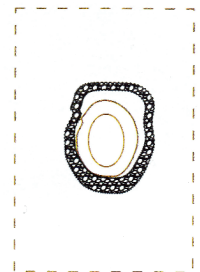

d)

Obr. 2 Účinky požáru na dřevěný trám, odhořivání jednotlivých vrstev [5].

Průběh vystavení dřevěného prvku účinkům požáru ze tř́i stran je patrný na Obr. 2 v pozicích a) až d). Rychlost zuhelnatění (viz výše) je závislá na době trvání účinků požáru. S rostoucím časem se tato rychlost snižuje v závislosti na tloušt'ce zuhelnatělé izolační vrstvy. Dřevěné prvky při požáru nevykazují známky nadměrných deformací, jako je tomu např. u ocelových konstrukcí. Dochází k postupnému odhořívání dřevní hmoty až do dosažení tzv. kritického průřezu, kdy nastává fáze destrukce [5].

Odhořívání dřevní hmoty je jev, kterému se při požáru nelze vyhnout. V rámci návrhu skladby konstrukce ze dřeva však lze oddálit dobu, kdy při požáru dojde ke vzplanutí dřevní hmoty a zvýšit tak dobu požární odolnosti. Jak bylo již zmíněno, jednou z nejběžnějších možností je užití retardéru ve formě jednovrstvých či vícevrstvých nehořlavých obkladových materiálů. Pro dřevostavby jsou nejčastěji využivány sádrokartonové či sádrovláknité desky s třídou reakce na oheň A2-s1, d0. Pro správnou funkci těchto materiálů je nutná jejich kvalitní aplikace včetně řešení jejich spojů. Spáry desek se řeší př̌evážně třemi základními způsoby, které jsou uvedené na Obr. 3.

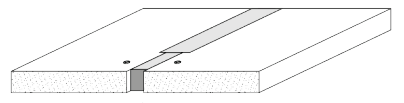

a)

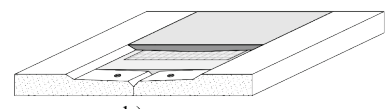

b)

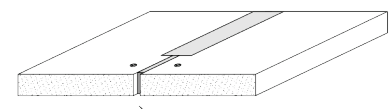

c)

Obr. 3 Možnosti řešení spár a spojů desek.

První z nich je řešení spoje za pomocí spáry vyplněné spárovacím tmelem. Š́řča takto provedené spáry se pohybuje okolo 5-10 mm. Toto řešení je patrné na Obr. 3 a). Další z možností je užití desek s profilovanou hranou. Tento typ spáry je doplněn výztužnou páskou vkládanou do vrstvy tmele - viz Obr. 3 b). Třetí možností bývá spoj desek tvořený lepenou spárou s šírkou okolo $1 \mathrm{~mm}$. Další možností spáry je těsný sraz natupo. Tento způsob aplikace se však nepouživá pro jednovrstvé opláštění a je možný pouze za použití další vrstvy desek s patřičným přesahem.

\section{METODIKA}

Pro experimentální zkoušení byla vybrána vnitřní dělící konstrukce lehké rámové dřevostavby. Dřevěná konstrukce byla tvořena profily ze smrkového řeziva s rozměry 60/100 mm s osovými vzdálenostmi $625 \mathrm{~mm}$. Prostor mezi profily byl vyplněn minerální tepelnou izolací na celou výšku dřevěných profilů. Konstrukce byla následně oboustranně opláštěna sádrovláknitými deskami tl. $12,5 \mathrm{~mm}$. Celková tloušt'ka konstrukce tak byla $125 \mathrm{~mm}$ s půdorysnými rozměry $2,3 \times 1,3 \mathrm{~m}$. Skladba zkušebního vzorku je popsána $\mathrm{v}$ Tab. 1 a znázorněna na Obr. 4 níže. Z hlediska českého zatřídění zkoušené konstrukce je skladba hodnocena jako druh konstrukční části typu DP2 [6].

Tab. 1 Skladba zkoušené konstrukce.

\begin{tabular}{ccccc}
\hline Ozn. & Název vrstvy & Charakteristika vrstvy & Tloušt'ka & Charakt. \\
{$[\mathbf{m m}]$} & PO \\
\hline $\mathbf{1}$ & Krycí vrstva & Sádrovláknitá deska & 12,5 & A2-s1, d0 \\
$\mathbf{2}$ & Rámová konstrukce & KVH profily 60/100 mm (smrkové řezivo) & 100,0 & D-s2, d0 \\
$\mathbf{3}$ & Výplňová izolace & Desky z čedičové vlny & 100,0 & A1 \\
$\mathbf{4}$ & Krycí vrstva & Sádrovláknitá deska & 12,5 & A2-s1, d0 \\
\hline
\end{tabular}

Konstrukce byla zkoušena na zařízení pro testování chování materiálů za vysokých teplot se zkušební plochou $2 \times 1 \mathrm{~m}$. Vzorek tak byl zkoušen se zmenšenými půdorysnými rozměry oproti normovému zkušebnímu postupu. Teplotní zatěžování probíhalo dle standartních podmínek podle závislosti logaritmické normové teplotní 
křivky [7]. V průběhu celé zkoušky byly kontinuálně měřeny teploty jak v konstrukci na rozhraní jednotlivých vrstev $\mathrm{v}$ různých místech, tak na neexponovaném povrchu konstrukce. Výsledné hodnoty byly porovnány s průběhem zkoušky dle standartního normového postupu certifikované skladby konstrukce.

Sádrovláknité desky byly připevněny ke konstrukci dřevěného rámu s použitím výše uvedených variant řešení spojů desek - viz Obr. 3 .

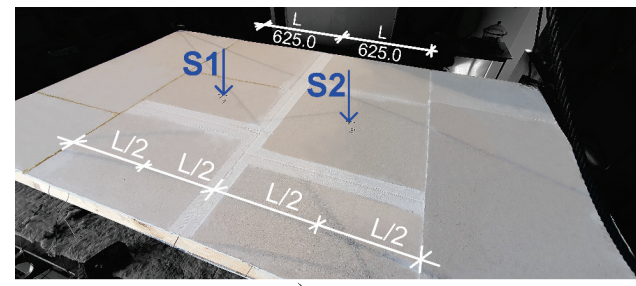

a)

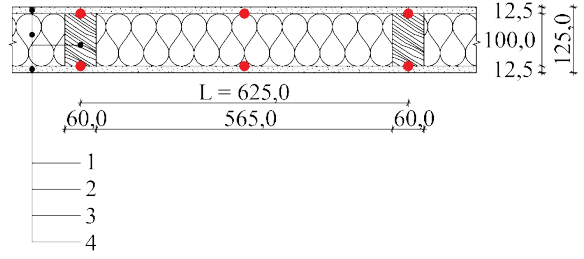

b)

Obr. 4 a) Konstrukce před zahájením zkoušky; b) Schematické znázornění skladby konstrukce.

\section{VÝSLEDKY}

Teploty mezi izolací a sádrovláknitou deskou na exponované straně konstrukce byly v porovnání s referenční zkouškou dle normového postupu nižší. Přibližně ve 40 minutě od zahájení zkoušky došlo k vyrovnání hodnot a teploty byly téměř identické s hodnotami z normových zkoušek.

$\mathrm{Na}$ exponované straně konstrukce byly nejnižší hodnoty teplot naměřeny mezi dřevěným prvkem a sádrovláknitou deskou s lepeným spojem. Mezi deskou a izolací v ploše konstrukce byly nejnižší hodnoty zaznamenány v místech se spojem desek s profilovanou hranou.

$\mathrm{Na}$ straně neexponované pak byly teploty nejnižší opět v místech mezi dřevěným prvkem a krycí deskou. Hodnoty v místě spoje s profilovanou hranou byly nepatrně nižší než v místě tmeleného spoje.

Pro stanovení izolační schopnosti konstrukce byly měřeny teploty na neohřívaném povrchu konstrukce. V porovnání s referenční zkouškou byly tyto př́růstky teplot totožné a hodnoty nepřesáhly navýšení o více jak 108 K. K porušení vzorku došlo v ploše konstrukce mezi dřevěnými sloupky okolo 50 minuty, kdy se na povrchu sádrovláknité desky vytvořily trhliny a zkouška byla ukončena.

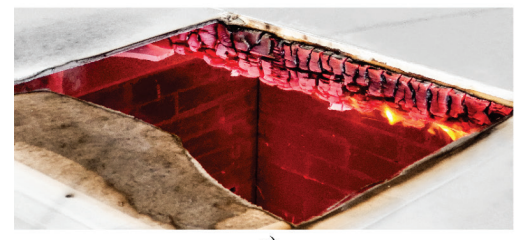

a)

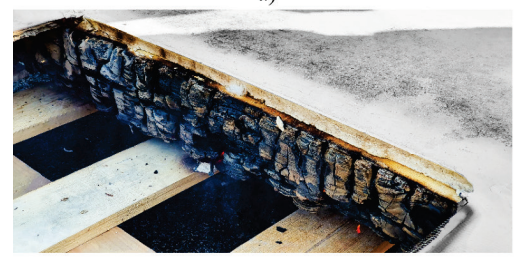

b)

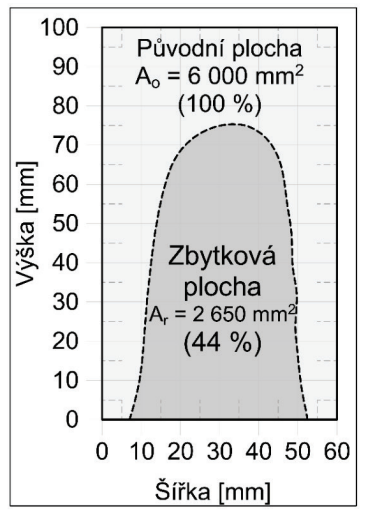

c)

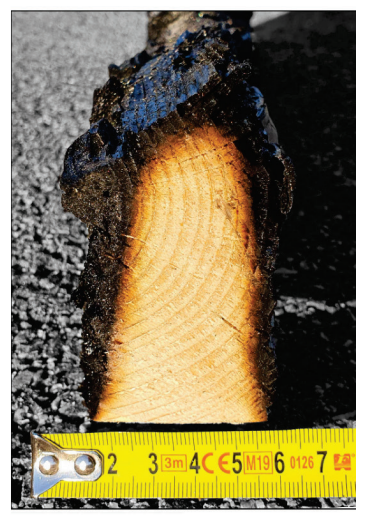

Obr. 5 a) Zuhelnatění dřeva před ukončením zkoušky; b) Zuhelnatění dřeva po skončení zkoušky; c) Řez dřevěným prvkem po ukončení zkoušky.

Na základě sledovaných kritérií v průběhu zkoušky byly vyhodnoceny mezní stavy požární odolnosti dle normových požadavků [8]. Vzhledem k vytvoření trhliny na neohřívaném povrchu konstrukce okolo 50 minuty došlo k porušení mezního stavu celistvosti. Trhlina se vytvořila v okolí bodu S2 - viz Obr. 4 a), kde byly zároveň měřeny největší přírůstky povrchové teploty během celé zkoušky. V době před ukončením zkoušky byl maximální 
přírůstek teploty na neohřívaném povrchu konstrukce okolo $108 \mathrm{~K}$. Tento přírůstek nedosahuje limitních hodnot (180 K, respektive $140 \mathrm{~K})$ a konstrukce tak vyhověla požadavkům pro mezní stav izolace.

Zatřídění druhu konstrukční části bylo určeno na základě teplot mezi dřevěným prvkem a sádrovláknitou deskou na ohřívané straně konstrukce. Teploty v této pozici začaly prudce narůstat okolo 22 minuty a krycí deska tak přestala plnit svoji funkci. Na základě klasifikačních dob tak lze konstrukci zatřídit jako DP2 do doby 15 minut a od této doby pouze jako DP3.

\section{DISKUZE}

Na základě dosažených výsledků ze zkoušky lze konstrukci vyhodnotit s mezními stavy EI 15 druhu konstrukční části typu DP2 a následně jako EI 45 s druhem konstrukční části typu DP3. Vzhledem k teplotám z termočlánků uvnitř konstrukce lze stanovit odolnost sádrovláknité desky tl. 12,5 mm na 15 minut (respektive 20 - 25 minut).

Nejpříznivější hodnoty za sádrovláknitou deskou z neohřívané strany byly naměřeny v pozici spojů desek $\mathrm{s}$ profilovanou hranou a výztužnou páskou, a to jak v ploše, tak v místě dřevěného prvku. Vzhledem k celkovému průběhu však byly rozdíly mezi těmito teplotami v řádu jednotek.

Konstrukce (vzhledem k možnostem zkušebního zařízení) nebyla namáhána silovými účinky zatížení a mezní stav nosnosti tak nebyl monitorován. Nicméně jak je patrné z Obr. 5 c) zbytková plocha nepoškozeného dřevěného průřezu po skončení zkoušky byla stále okolo 40 \% z celkové původní průřezové plochy.

\section{ZÁVĚR}

Požární odolnost dřevěných konstrukcí je důležitým faktorem pro návrh dřevostaveb a jejich další rozvoj a využitelnost i mimo oblast rodinných domů. Dřevo je díky předvídatelnému chování při jeho hoření vhodným a udržitelným materiálem pro konstrukce pozemních staveb. Užitím nehořlavých obkladových materiálů, dostatečnou dimenzí dřevěných prvků, případně užitím aktivních prvků požární ochrany jsou tyto konstrukce vhodné nejen z hlediska ekologického, ale i z hlediska požární odolnosti. Důležitým faktorem je však nejen správný projekční př́stup, ale i preciznost při realizaci dřevostaveb a jejich detailů. Konstrukce s dřevěnými prvky dokážou při správném návrhu a použití odolávat účinkům požáru a splňovat poměrně vysoké požadavky mezních stavů požární odolnosti.

\section{Poděkování}

Tento článek vznikl za podpory Fakulty stavební Vysokého učení technického v Brně v rámci projektu specifického výzkumu FAST-J-21-7373. Pro experimentální testování bylo využito zařízení výzkumného centra AdMaS (Advanced Materials, Structures and Technologies).

\section{Použité zdroje}

[1] Bisby, L., Gales, J. \& Maluk, C. A contemporary review of large-scale non-standard structural fire testing. Fire Sci Rev 2, 1 (2013). https://doi.org/10.1186/2193-0414-2-1.

[2] Le, Ha Truong Di \& Tsai, Mengting. Experimental Assessment of the Fire Resistance Mechanisms of Timber-Steel Composites. Materials. 12. 4003. 10.3390/ma12234003. 2019.

[3] OSVALD, Anton a Jozef ŠTEFKO, SEIDL, Miloslav, ed. Modelový požiar dvojpodlažnej drevostavby. Žilinská univerzita v Žilině: ŠMÍRA-PRINT, s.r.o., Ostrava, 2013. ISBN 978-80-87427-85-9.

[4] White, R.H. \& Dietenberger, Mark. Wood Products: Thermal Degradation and Fire. 10.1016/B0-08043152-6/01763-0. 2001.

[5] KRATOCHVÍL, Václav, Šárka NAVAROVÁ a Michal KRATOCHVÍL. Požárně bezpečnostní zařízení ve stavbách: stručná encyklopedie pro jednotky PO, požární prevenci a odbornou veřejnost. II. doplněné a upravené vydání. Praha: Sdružení požárního a bezpečnostního inženýrství, 2021. ISBN 978-80-7385-238-2.

[6] ČSN 730810 Požární bezpečnost staveb - Společná ustanovení. Praha: ÚNMZ. 2016.

[7] ISO 834, "Fire Resistance Tests-Elements of Building Constructions," International Standard ISO 834, 1975.

[8] ČSN EN 13501-2 Požární klasifikace stavebních výrobků a konstrukcí staveb - Č́st 2: Klasifikace podle výsledků zkoušek požární odolnosti kromě vzduchotechnických zařízení. Praha: ÚNMZ. 2017. 